\title{
EquiLIBRIUM
}

Quarterly Journal of Economics and Economic Policy

2015 VOLUME 10 ISSUE 2, June

p-ISSN 1689-765X, e-ISSN 2353-3293

www.economic-policy.pl

Miłek, D., \& Nowak, P. (2015). Regional Specialisation as an Endogenous Factor in the Development of Poland's Provinces. Equilibrium. Quarterly Journal of Economics and Economic Policy, 10(2), pp. 115-135, DOI: http://dx.doi.org/10.12775/ EQUIL.2015.016

Dorota Miłek, Paulina Nowak*

Kielce University of Technology, Poland

\section{Regional Specialisation as an Endogenous Factor in the Development of Poland's Provinces}

JEL Classification: $A 11 ; B 16$

Keywords: economic development of the country; regional innovation policy; regional specialisation; Krugman index

\begin{abstract}
The economic development of Poland and its regions results from a complex interaction of many factors, which include regional innovation policy. The task of regional innovation policy is to identify and develop smart specialisations, which may offer an opportunity of building up sustained competitive advantage of Poland's provinces. The identification of regional specialisations for the needs of regional policy carried out by Poland's provinces is a complex process. It must be placed within the context of all other processes of territorial development. To formulate specialisations, it is necessary to perform a thorough analysis of regional economic structures, taking into account both the resources of a given region and possibilities of generating revenue. One of the methods used to identify potential regional specialisations is the Krugman dissimilarity index. In the paper, it is employed to analyse the dissimilarities between the economic structures of Poland's regions.
\end{abstract}

(C) Copyright Institute of Economic Research \& Polish Economic Society Branch in Toruń Date of submission: December 12, 2014; date of acceptance: May 8, 2015

*Contact: dorothy@tu.kielce.pl pnowak@tu.kielce.pl, Kielce University of Technology, Al. Tysiąclecia PP 7, 25-214 Kielce, Poland 


\section{Introduction}

Regional development is a result of the interaction of many factors, including the development policy. Development priorities, presented in strategic documents, such as regional innovation strategies, emphasise building up the region's competitive advantage by means of the identification and development of regional specialisations. This notion is applicable to the development policy, especially that of a region. The policy assumptions draw on the well-known theories of the regional development. In the concept of intelligent specialisations, it is assumed that in the efforts aimed at development, a region should focus on a small, definite number of priorities which have significant innovation potential. The regional authorities need to recognize the strong and weak points of a given area and focus on innovation.

The objective of the paper is to make a diagnosis of specialisations of Poland's provinces. Another aim is an attempt at the validation of specialisations against the regional innovation policy, which was done on the example of the Świętokrzyskie Province. In the paper, the Krugman index of dissimilarity was employed. The index is calculated on the basis of comparison of the economic structure of a given region with the average economic structure of the remaining regions.

\section{Specialisation in the Regional and Local Development Theories}

Specialisation is a widely used notion in the theory of regional and local development. Individuals, societies and states tend to specialise in different fields, and the specialisation of regions and countries has been in the scope of interest of economists for hundreds of years (Miłek, 2013, p. 191). Region's specialisation is also present in the concept of a region itself. Kuciński describes a region as a "set of adjacent areas (basic units in the geographical space) which, in respect to certain criteria, share as many features as possible, and show as many differences as possible from the surrounding space" (Kuciński, 1990, p. 17).

Thus, the specialisation of an economic region is considered to be its specific feature, which can be described as possessing a clearly defined profile of manufacturing, with a strongly developed sector of economy, or a type of manufactured products. The profile features the specialisation that is dominant in the space being investigated. It is also a major source of employment and contributes most to the region's share in GDP. Specialisa- 
tion can also originate in the uniqueness of the region, then, it indicates the type of activity that is found exclusively in this particular region.

At present, in the regional economy, the process of the regional policy optimisation is observed. That is done by means of adapting the existing regional development theories to the prevalent social and economic conditions. To a lesser extent, the theories are also used to formulate new concepts of regional development. The notion of specialisation is also related to the existing theories that have been worked on for many years. Those include the following: the basic product theory, the concept of flexible production and specialisation, the concept of territorial production systems, and the concept of industrial clusters.

In accordance with the basic product theory by Innes, production specialisation leads to regional development. The author assumes that specialisation means focusing on a selected group of products which may be most competitive on the external markets. Top quality of the products manufactured, continually improved organisation of production and reduced transactional costs contribute to specialisation-induced advantages. Advanced production specialisation provides an explanation for another concept, the so-called new trade theory. According to this theory, regional development in export activities results from specialisation in labour-consuming production in the regions that have large resources of cheap workforce, and also specialisation in capital-consuming production in the regions that have vast capital resources (Grosse, 2002, p. 27).

The concept of flexible production and specialisation is based on specialised small and medium-sized businesses. The companies that make the system operate in close cooperation resulting from historical entrepreneurial traditions and social relations based on mutual trust. Specialised manufacturers from small and medium-sized companies find it easier to launch a new range of products, and to adapt to changing market conditions and consumers' choices, which gives them a competitive advantage. A dynamic development of regional economy originates in the cooperation of the system participants, who due to mutual trust, make their activities more effective and reduce the transactional costs (Grosse, 2002, p. 33).

In his theory of growth poles, Perroux also emphasises specialisation, which can provide a development opportunity in the spatial aspect. The author indicates the concentration of activities in the most developed companies, sectors and industries will account for a dynamic development of the region. The theory is one of the most widely used concepts that emphasise the role of spatial concentration in regional development. The growth poles are the best developed industries and sectors which act as "development engines". That means the theory assumptions refer primarily to devel- 
oped areas, usually metropolises, the functions of which dominate over those of the remaining areas. It happens so because of their capabilities of attracting technologically advanced industries, which ensures high competitiveness and dominance over areas that have weaker economy. According to this theory, the growth poles are not individual companies, but their clusters in a defined space, where mutual interactions stimulate territorial development (Szewczuk et al., 2011, p. 41).

A form of organizing production, termed industrial district, proposed by Marshall is based on extra-market relations and social division of labour between companies which specialise in individual stages of the production process. The district is a specified area, in which specialised industrial companies run their business. The author believed the concentration would provide an opportunity for collective learning due to the spread of innovation by the exchange of information between the economic entities. The cumulative process of the exchange of information on technology issues, marketing and financial services ensures a wide spectrum of specialised services related to local production (Grosse, 2002, pp. 33-35).

A set of specialised companies also plays an important role in the concept of Italian industrial districts. The core of the set is composed of small and medium-sized firms embedded within a local network. Their activities are based not only on trade agreements, but also on social, especially family relations. Those firms, specialising mainly in traditional industries, like textiles, clothing, furniture and food, have operated successfully on international markets. Italian districts, as a rule, are composed of companies operating in a single industry, and specialising in a specific production process stage. A characteristic feature of Italian industrial districts is their high flexibility, which results from the ability to adapt to changes and to create new solutions, also innovative ones.

The organizing of specialised production is also present in the so-called new industrial districts proposed by Markusen. Three types of districts, defined by the author, specify the spatially restricted zone of economic activity having a clearly characterised economic specialisation. It results from the possessed resources and may refer to industrial or service activities. That is particularly present in the first district type defined by Markusen, which is termed a radial layout district. In thus organised production, the local culture, based on specialisation activities, promotes technical knowledge, specific competences and new services.

The specialisation process is a matter of consideration in technopolises, i.e. specific industrial districts, based on modern technologies. Established in Europe starting from the 1960s, those pursued research activities in the fields related to the region's or city's strong points. The concentration of 
means in the areas of a given region that had the development potential was thought to encourage local communities to create technology poles, intended to design and sell advanced technologies. Those are related to the growth poles advocated by Perroux in the second half of the 20th century. The development of new technologies is enhanced by the synergistic effect and external benefits. It is supported by the local authorities, whose task is to provide infrastructure, namely incubators, innovation centres, and technology parks. Local communities are engaged in the development of technology poles, which often leads to the identification of specific cities as "technopoles". That inspired the creation of the concept of technopolis, i.e. a city developing through the sales of technologies (Jewtuchowicz, 2013, pp. 77-88).

The operation, in a given territory, of a set of specialised firms underlies the notion of territorial production systems, the formation of which shows the abilities of local economies to adapt to globalisation. The systems develop all over the world at the sites of operation of specialised companies characterised by flexible production. In the system, the companies with a clear profile operate within the network of internal and external cooperation links and gain benefits from concentration (agglomeration). Development of territorial production systems is conditioned by the growth potentials, often unique in character. The conditions also include the local participants' capability of establishing partnership relations with different institutions in a given region (Jewtuchowicz, 2013, pp. 90-94).

Specialised companies also constitute important components in industrial conglomerates described in the literature by Porter. In a given region, local industrial groups acquire knowledge and technologies, which accounts for competitive advantage. Specialised firms, linked to business environment institutions and research centres, establish long-lasting interactions. The conglomerates are created in both traditional and innovative sectors of economy, as a result networks of specialised suppliers are built, in which much emphasis is placed on R\&D and product innovation (e.g. networks of companies producing software and hardware). Geographical concentration of businesses and institutions of a given industry promotes the formation of the network of suppliers and subcontractors, thus contributing to the region's specialisation in different economy sectors (Porter, 2001, pp. 245-342; Grosse, 2002, pp. 36-38).

Considered as a model, regional specialisation is a template for spatial development, based to a great extent on endogenous resources. That is confirmed by the factors which are necessary for the selection of a given economy sector as a regional specialisation, e.g. raw materials in the mining industry or outstanding natural features in the tourist industry 
(Kopczewska, 2011, p. 92). Those, however, are not sufficient for specialisation development in certain sectors. In the new trade theory, specialisation is stimulated by increasing revenue of scale, perfect monopolistic competition (the Chamberlin's model), and the manufacture of different types of the same goods (Krugman, 1979, pp. 469-479). In the so-called new economic geography, the spatial patterns of agglomerations are emphasised, which are meant to lead to specialisation. The investigations on the factors of regional development in Central and Eastern Europe show that in addition to convergence processes, equally strong divergence processes occur. That especially refers to peripheral areas. The crucial aspect of the differentiation is the dichotomy between highly developed, innovative metropolitan areas specialising in innovative sectors and the remaining areas. Presently, agglomerations are leading development centres due to the functions they perform. Managerial functions in the world's economy are of special importance and agglomerations hold seats of transnational corporations and specialist companies, innovative in character. Additionally, agglomerations provide economic, social and institutional environment which is beneficial to innovation (Smętkowski, Płoszaj, 2011, p. 10). Therefore, it should be emphasised that although regional development is based on the utilisation of internal resources, yet it is equally important that those areas need to operate in the interregional and international network systems.

Although related to the "old" concepts of regional development, regional specialisations are present in a new approach adopted in the regional policy of the EU. The new standpoint emphasises the innovative character of regional specialisations, hence they are termed smart specialisations.

\section{Smart Specialisation as a Priority in Regional Innovation Policy}

In recent years, the concept of creating regional specialisations has become a determinant of regional and local development in the EU member states. It is compliant with one of the main three priorities in the Europe 2020 Strategy, which concerns development based on knowledge and innovation $^{1}$. In the concept of smart specialisations, it is assumed that a region should focus the pro-development efforts on a small number of defined priorities that have considerable innovation potential. Therefore, the launch

\footnotetext{
${ }^{1}$ The term smart specialisation was used in the European Union strategic document $E u$ rope 2020 - A Strategy for Smart, Sustainable and Inclusive Growth published by the European Committee in 2010 (A Strategy for... 2010).
} 
of the new operational programmes for the years 2014-2020, co-funded by the UE, is related to the necessity of designing a regional strategy for smart specialisations (RIS3). The implementation of the Europe 2020 Strategy means Poland's regions need to identify the priority areas, which are supported by the EU funding.

The identification of regional specialisations for the sake of the regional policy is a complex task, which must be placed against the background of all processes of regional and local development. Specialisation can, and should be treated as trajectory ${ }^{2}$ of the territory development. The condition necessary for development concerns a sound economic structure of the region, in which a clearly dominant industrial activity, or a regional product is found. The production system constructed in this way relies on the development of a specific industry, geographical proximity, and mutual production and organisational relations between the participants. The technological aspects are by no means less important. Those involve access to education centres related to the specialisation, or to technical centres that provide technological support and improve the skills of the human capital.

Geographical and organisational proximity enhances the processes of activity coordination of the entities taking part in the formation and development of regional specialisation. While cooperating, the participants in the process combine their individual development strategies and benefit from the common good which originates in collaboration.

The creation of specialisation can result from operational strategies of private businesses which utilise the availability of the specific resources and manufacture the same products. When competing with one another, they contribute to the concentration of a certain type of activities and firms. The industrial links established between the companies enhance the specialisation processes. Specialisation may also originate in the policy of local authorities and state-run policies. Working towards increased territorial competiveness, the authorities may facilitate the accumulation of specific assets. In this way, the risk of business relocation is reduced, whereas the advantages resulting from the extension of technical knowledge in a given field are increased [Jewtuchowicz, 2013, pp.131-133].

In the process, the regional innovation potential, based on the resources and possibilities available in the region, is assessed. The areas that are identified should be decisive for the region's competitive advantage. Those can include specialisations within one sector or inter-sector activities, which

\footnotetext{
${ }^{2}$ Specialisation, agglomeration and specificity were the terms employed by Colletis, and Pecquer et al. In the investigations into the territory-company relations, the above mentioned notions established the trajectories of territorial development (Jewtuchowicz, 2013, pp. 129130).
} 
ensure a specific competitive advantage. The objective is to establish social and economic identity of the region, it is therefore crucial in the process of selecting smart specialisation to take a well-thought-out decision. Distinctive choice will make it possible to avoid copying the solutions selected in other regions [Pieńkowski].

Identified specialisations are enumerated in regional innovation strategies for smart specialisations RIS3. Those constitute an important component of the region's development policy.

\section{Methodology of Investigations}

Regional specialisation is most often identified by comparing the region's economic/employment structure with the averaged structure of all the country's regions. A region shows a strong regional specialisation if its economic/employment structure for a given industry is different from that typical of the regions (Bąk et al., 2008, p. 31). The level of regional specialisation is assessed using indices of specialisation (dissimilarity), especially designed for the task. In empirical investigations, the Gini or Krugman specialisation indices are employed. In the present study, the Krugman index was used to investigate specialisation patterns in Poland's regions. The Krugman index is defined as follows (Chmielewski, 2010, p. 4):

$$
K S_{j}=\sum_{i=1}^{n}\left|X_{i j}-\bar{X}_{i l}\right|
$$

where:

$j$ - the region's index,

$X_{i j}$ - share of those employed in the industry $i$ in the region $j$ (in accordance with GVA);

$\bar{X}_{i l}$ - mean share of those employed (in accordance with GVA) in the industry $i$ in all other regions, excluding the province $j$.

The Krugman specialisation index ranges from 0 to 2 . The value of 0 indicates the region's economic structure is the same as an average economic structure in other regions. On the contrary, the value of 2 shows that the region's economic structure is totally different from the country's average (Krugman, 1991, pp. 75-76). 
To determine regional specialisation of the provinces, the analysis was made and indices were calculated on the basis of the following data:

- the number of the employees arranged by sections - Polish Classification of Activities (PKD), compiled on the basis of Statistical Classification of Economic Activities in the European Community - NACE, in 2012,

- Gross Value Added arranged by PKD sections - in 2011.

Due to the availability of the statistical data, the Krugman indices as regards employees in individual regions were calculated for the following PKD sections: Agriculture, forestry, and fishing; Industry; Construction; Trade, repair of motor vehicles; Transportation and storage, Accommodation and catering; Information and communications; Financial and insurance activities; Real estate activities; Professional, scientific and technical activities; Administrative and support service activities; Public administration and defence, compulsory social security; Education; Human health and social work activities; Arts, entertainment and recreation; Other service activities. The indices based on GVA were calculated for the following sections: Agriculture, forestry, and fishing; Industry; Construction; Trade, repair of motor vehicles; Financial and insurance activities; Other service activities. For both groups, the synthetic Krugman index, which defines the degree of regional specialisation, was computed.

It should be noted that such an approach allows for a comparison of engagement of a given province in sector activities with respect of the engagement of the whole country in this sector. However, this approach does not make it possible to draw conclusions on the spatial economic activities, e.g. of companies representing a given sector, as those may be concentrated in a small part of the region of concern (Kopczewska, 2010, p. 94).

\section{Specialisation of Poland's Provinces on the Basis of Employees}

The specialisation index calculated on the basis of employees by PKD sections for Poland's provinces ranged from 0.112 to 0.468 (see Table 1). The level of specialisation in the Lubelskie Province is four times higher than that of the Łódzkie Province. The former province, with the most dissimilar structure of employment, shows 0.130 score difference compared with the successive regions. A relatively high level of specialisation is also found in the Podkarpackie, Świętokrzyskie, Podlaskie and Mazowieckie provinces, in which the index exceeds the value of 0.3 . 
A high level of dissimilarity of the employment structure in provinces located in the east of Poland results from a high share of individuals employed in agriculture. The Krugman index for those provinces in the section of agriculture, forestry, and fishing was above 0.15 . The employment in agriculture in those provinces constitutes at least $32 \%$ of the structure, and for the Lubelskie Province, the value is almost $39 \%$.

Table 1. The Krugman index of regional specialisation on the basis of employees in 2012

\begin{tabular}{|l|l|c|}
\hline Nb. & \multicolumn{1}{|c|}{ Province } & $\begin{array}{c}\text { The Krugman index of } \\
\text { regional specialisation }\end{array}$ \\
\hline 1. & Lubelskie & 0,468 \\
\hline 2. & Podkarpackie & 0,338 \\
\hline 3. & Świętokrzyskie & 0,335 \\
\hline 4. & Podlaskie & 0,330 \\
\hline 5. & Mazowieckie & 0,301 \\
\hline 6. & Śląskie & 0,284 \\
\hline 7. & Lubuskie & 0,205 \\
\hline 8. & Pomorskie & 0,201 \\
\hline 9. & Zachodniopomorskie & 0,193 \\
\hline 10. & Dolnośląskie & 0,185 \\
\hline 11. & Małopolskie & 0,161 \\
\hline 12. & Wielkopolskie & 0,156 \\
\hline 13. & Opolskie & 0,150 \\
\hline 14. & Warmińsko-mazurskie & 0,146 \\
\hline 15. & Kujawsko-pomorskie & 0,123 \\
\hline 16. & Łódzkie & 0,112 \\
\hline
\end{tabular}

Source: the author's calculations.

A high level of specialisation of the Mazowieckie Province is affected by relatively high indices (ranging from 0.065 to 0.036 ) in individual sections, especially in industrial processing, agriculture and also professional, scientific and technical activities. A slightly lower Krugman index is assigned to the Śląskie Province, which is differentiated by a high share of industry in the structure of employees in the region (30\%). 
The index marginally higher than 0.2 was found for the Lubuskie and Pomorskie provinces. In the first one, the highest partial indices are noted for agriculture and industrial processing (0.06 and 0.05 , respectively). In the other region, the highest partial indices are observed for agriculture, industrial processing and construction (from 0.02 to 0.08 ).

The lowest level of specialisation is found in the following provinces: Łódzkie, Kujawsko-Pomorskie and Warmińsko-Mazurskie. In those regions, the dissimilarity index did not exceed 0.15 , which means the employment structure by industries most resembles the average structure in the remaining regions. In the structure of the employees, the following are prevalent: the industrial processing (approx. 20\% of employees), agriculture (slightly less than 20\%), and repair of motor vehicles (approx. 15\%).

\section{Specialisation of Poland's Provinces on the Basis of Gross Value Added}

Specialisations based on the employment structure do not show congruence with the indices of regional specialisation based on the Gross Value Added (see Table 2).

The index values based on GVA are also lower than those calculated on the basis of the number of employees. Three provinces with the highest specialisation level, namely Mazowieckie, Dolnośląskie and Śląskie show the values ranging from 0.288 to 0.224 . Their dissimilarity in comparison with the remaining regions results from high specialisation indices in the industry section. It should also be noted that the respective values: 0.126 , 0.122 and 0.112 are the highest partial specialisation indices, calculated on the basis of GVA, among all Poland's provinces. The Mazowieckie Province is also characterised by high indices of regional specialisation in the following sections: financial activities and trade, and at the same time, the lowest ones in the section of agriculture. The fourth place in the category of most dissimilar structure of manufacturing is occupied by the Podlaskie Province, which was also the fourth when the calculations were made on the basis of employees. The level of difference in the structure in this region, calculated on the basis of GVA, is primarily affected by the high Krugman index of dissimilarity in the agriculture section. It reached the value of 0.071 and was by far the highest among all Poland's provinces. 
Table 2. The Krugman index of regional specialisation on the basis of GVA in 2011

\begin{tabular}{|l|l|c|}
\hline Nb. & \multicolumn{1}{|c|}{ Province } & $\begin{array}{c}\text { The Krugman index of } \\
\text { regional specialisation }\end{array}$ \\
\hline 1. & Mazowieckie & 0,288 \\
\hline 2. & Dolnośląskie & 0,245 \\
\hline 3. & Śląskie & 0,224 \\
\hline 4. & Podlaskie & 0,177 \\
\hline 5. & Lubelskie & 0,166 \\
\hline 6. & Małopolskie & 0,144 \\
\hline 7. & Zachodniopomorskie & 0,134 \\
\hline 8. & Opolskie & 0,134 \\
\hline 9. & Warmińsko-mazurskie & 0,129 \\
\hline 10. & Lubuskie & 0,124 \\
\hline 11. & Wielkopolskie & 0,111 \\
\hline 12. & Łódzkie & 0,107 \\
\hline 13. & Podkarpackie & 0,099 \\
\hline 14. & Świętokrzyskie & 0,095 \\
\hline 15. & Kujawsko-pomorskie & 0,064 \\
\hline 16. & Pomorskie & 0,044 \\
\hline
\end{tabular}

Source: the author's calculations.

The region showing the lowest specialisation is the Pomorskie Province, where the index does not exceed the value of 0.044 . Thus, the difference between the provinces having the highest and the lowest level of regional specialisation, based on GVA, amounts to 0.244. In addition to the Pomorskie Province, also the Kujawsko-Pomorskie, Świętokrzyskie and Podkarpackie provinces showed the index values below 0.1, which indicates their structures of manufacturing (GVA) are most similar to the country's average structure. It is worth mentioning that the Kujawsko-Pomorskie Province is positioned in the last but one place in both rankings. In this province, low dissimilarity of the structure of employees is accompanied by the low dissimilarity of the structure of manufacturing GVA. The Podkarpackie and Świętokrzyskie provinces are considered a special case, because being in leading positions as regards the most specialised structure in the classification based on employees (the second and third place, respectively), they are at the end of the list of provinces (the thirteenth and four- 
teenth, respectively) with respect to specialisation ranking based on GVA. Both regions have the lowest share in GVA in the section of financial activity, and a relatively low share in the following sections: trade, and also other services.

\section{Vertical and Horizontal Coherence Between Regional Specialisations and RIS3 Assumptions on the Example of the Świętokrzyskie Province}

Europe 2020 - A strategy for smart, sustainable and inclusive growth, was adopted by the European Commission in March 2010. One of the three priorities determined in this document is smart development, i.e. that based on knowledge and innovation. In order for this approach to be implemented, the EU member states and their regions need to design strategies for smart specialisations.

Regional specialisations selected and accepted in the regional strategy for smart specialisation (RIS3) need to comply with smart specialisations listed in the documents compiled at the national level (vertical coherence) ${ }^{3}$. It is also important that the actual specialisations found in the region should be congruent with RIS3 assumptions (horizontal coherence). This coherence is enforced by the opportunity offered to the regions to support research, development and innovation (RDI) within the frames of the financial perspective for the years 2014-2020.

The strategic frames for the country's smart specialisations have been defined in one of the nine integrated strategies entitled Strategy for an Innovative and Efficient Economy Dynamic Poland 2020 (Strategia Innowacyjności..., 2013). The assumptions made in the document are coherent with Europe 2020 development strategy and the principles of the medium-term National Development Strategy 2020 (National Smart..., 2014). The implementation document for the Strategy for Innovation and Effectiveness in the Economy is the Programme of Enterprise Development until 2020 which provides a comprehensive set of support measures aimed at the development of innovation and entrepreneurship in Poland. An integral part of the latter document is the National Strategy for Smart Speciali-

\footnotetext{
${ }^{3}$ Regional smart specialisations need to show congruence with the assumptions of the Europe 2020 Strategy. In Poland, the work on the identification of those was carried out separately at national and regional levels. Consequently, the national smart specialisations were not recognised as superior to specialisations identified at the regional level (National Smart..., 2014, p. 45).
} 
sation. It indicates research, development and innovation areas on which activities should focus in order to achieve the strategic goals.

The point of departure for identifying the national smart specialisations in Poland is provided by two key documents on science, research and innovation, namely:

- Technology Foresight for Industry - InSight2030, compiled on the order of the Ministry of Economy, which lists 99 technologies categorised into 10 research fields.

- National Research Programme, designed by the Ministry of Science and Higher Education, which comprises seven interdisciplinary trends in research and development.

In addition to the two items mentioned above, another relevant document is the Polish Roadmap for Research Infrastructure, which comprises several dozen projects aimed at the development of science and economy in Poland. The project address the concept of establishing research centres that would consolidate the national scientific potential (Strategia Innowacyjności..., 2013).

To define national smart specialisations, the Ministry of Economy designed the selection methodology, on the basis of which 37 areas (at the successive stage, as a result of aggregation, their number was reduced to 22) were chosen. This is the point of departure for the determination of specialisations (National Smart Specialisation, 2014). Finally, 18 national smart specialisations were identified through the verification process. Those were categorised into five thematic areas: healthy society, bioeconomy covering the following: agriculture and food, forestry and timber, and also the environment, sustainable power engineering, natural raw materials and waste management, and also innovative technologies and industrial processes (horizontal approach).

In the Świętokrzyskie Province, four sectors of economy which constitute the region's specialisations were identified, namely metallurgy and foundry, resource-efficient construction, health and health-related tourism, modern agriculture and food processing. Those are supported by three horizontal areas, namely information and communication technologies (ICT), sustainable energy development, and also fairs and congress business. The choice of smart specialisations was based their economic and scientific potential and current contribution to the economy of the province. As emphasised by the RIS3 authors, in the selection made by the Świętokrzyskie Province the available data were utilised and four methods were employed. Those included the following: the analysis of the science potential, the analysis of the economic strengths of the province, the foresight analysis and the market selection method (auto-selection) (Research and Innovation 
Strategy (RIS3).., 2014, pp. 32-37). The smart specialisations selected for the province coincide, to a major extent, with those identified at the national level. The selected specialisations at the national and regional level are coherent although it was not required that the national smart specialisations should be superior to those defined at the regional level.

As it was assumed in the National Strategy for Regional Development "the need for fast development calls for focusing regional policy on the optimal use of the development potentials of individual regions for the success of the general development strategy" (National Strategy for..., 2010, p. 5). Thus, the development potentials of the regions should be compatible with the regional specialisations, additionally, the horizontal coherence needs to be maintained.

The Świętokrzyskie Province potential in specialisation can be diagnosed, among others, on the basis of the Krugman indices of dissimilarity. The values of this index, calculated for employees by PKD sections, amounted to 0.335 , which positioned the province in the third place in Poland (see Table 3).

Table 3. Indices of regional specialisation for the Świętokrzyskie Province on the basis of employees in 2012

\begin{tabular}{|l|c|}
\hline \multicolumn{2}{|c|}{$\begin{array}{c}\text { Regional specialisation in accordance with Krugman on the basis } \\
\text { of employees in PKD sections in 2012 }\end{array}$} \\
\hline Agriculture, forestry, and fishing & 0,162 \\
\hline Industry & 0,036 \\
\hline Construction & 0,005 \\
\hline Trade, repair of motor vehicles & 0,029 \\
\hline Transportation and storage & 0,011 \\
\hline Accommodation and catering & 0,007 \\
\hline Information and telecommunications & 0,013 \\
\hline Financial and insurance activities & 0,014 \\
\hline Real estate activities & 0,007 \\
\hline Professional, scientific and technical activities & 0,018 \\
\hline Administrative and support service activities & 0,011 \\
\hline Compulsory social security & 0,001 \\
\hline Education & 0,009 \\
\hline
\end{tabular}


Table 3 continued

\begin{tabular}{|l|c|}
\hline $\begin{array}{c}\text { Regional specialisation in accordance with Krugman on the basis } \\
\text { of employees in PKD sections in 2012 }\end{array}$ \\
\hline Human health and social work activities & 0,006 \\
\hline Arts, entertainment and recreation & 0,002 \\
\hline Other service activities & 0,005 \\
\hline The index of regional specialisation 0.335 \\
\hline
\end{tabular}

Source: the author's research.

As a result, it is possible to categorise the region as a highly specialised one. The high specialisation index is affected by higher than average employment in agriculture.

Industry, and also trade, repair of motor vehicles also contribute to the high specialisation index, but to a far lesser extent. The index values for those sections were 0.036 and 0.029 , respectively.

As regards the Gross Value Added in PKD sections for 2011, the Krugman index for the Świętokrzyskie Province took on the value of 0.095 (see Table 4). Due to GVA arrangement by PKD sections, the province can be categorised as weakly specialised.

Table 4. Indices of regional specialisation for the Świętokrzyskie Province on the basis of GVA in 2011

\begin{tabular}{|c|c|c|c|c|c|}
\hline \multicolumn{6}{|c|}{$\begin{array}{l}\text { Regional specialisation in accordance with Krugman on the basis of Gross Value } \\
\text { Added in PKD sections in } 2011\end{array}$} \\
\hline $\begin{array}{l}\text { Agriculture, } \\
\text { forestry, } \\
\text { and fishing }\end{array}$ & Industry & Construction & $\begin{array}{c}\text { Trade, } \\
\text { repair of } \\
\text { motor } \\
\text { vehicles } \\
\end{array}$ & $\begin{array}{c}\text { Financial } \\
\text { and } \\
\text { insurance } \\
\text { activities }\end{array}$ & $\begin{array}{c}\text { Other } \\
\text { service } \\
\text { activities }\end{array}$ \\
\hline 0,019 & 0,012 & 0,016 & 0,007 & 0,039 & 0,002 \\
\hline
\end{tabular}

Source: the author's research. 
The highest values of the Krugman index are noted for financial and insurance activities, to a far lesser extent GVA is generated in agriculture.

The values of the Krugman index for PKD sections, based on employees and GVA do not allow clear identification of the region's smart specialisations. Additionally, the defined regional specialisations were not described in details in RIS3, which makes it difficult to provide their complete characteristics. Only a few general conclusions can be drawn on the basis of the available data. The Krugman index took on the highest value for agriculture, which seems to confirm the choice of the specialisation of Modern Agriculture and Food Processing. Though the structure of the region's economy analysed with respect to employment shows high specialisation in the section of agriculture, however, it should be taken into account that results from the already existing unfavourable employment structure. A relatively high index found for the industrial processing section may indicate the development potential of the specialisations, defined in the RIS3, namely Metallurgy and Foundry and Resource-Efficient Construction. On the basis of the data available for the PKD section, it is difficult to comment on the Health and Health-Related Tourism specialisation.

The two of the selected regional specialisations are related to the prevalent industries in the province, namely construction, foundry and metallurgy. Those endogenous development potentials are related to the occurrence of mineral resources including rock raw materials, minerals for chemical and power industries, and also long mining and metallurgy traditions. Large mineral deposits provide a good basis for the production of the construction materials concentrated in many facilities where minerals are extracted and processed, in the country's largest manufacturing facilities of gypsum products, and in brickyards. The construction materials industry is mainly based on minerals, the deposits of which are unique in Poland. The major natural resources of the province include minerals, especially gypsum rock, the deposits of which are among the largest in Europe. The Świętokrzyskie Province is one of major manufacturers of gypsum, ceramic tiles, paving slabs, cement and mineral aggregates. The development of resourceefficient construction and that of metallurgy and foundry is also related to the existing science and research potential in construction materials, metal technologies and mechanical engineering. The research and invention output, and the unique research structure available at the Kielce University of Technology makes it possible to identify areas of the cooperation of researchers and local business people aimed at supporting regional specialisations. The cooperation areas comprise, among others, the following: technologies of metals (special alloys, welding and metal machining, also laser machining, surface treatment, finished metal products, parts for automotive 
industry, bearings), machines, and specialised equipment, e.g. for metrology and electrical engineering, innovative construction materials based on local raw materials: insulations, cements, asphalts, aggregates, ornamental stone, ecology and environmental technologies, including hydropower and eco-power.

A large share of agriculture in the economy is linked to the development of agricultural and food industry. The region holds the potential for the development of organic farming and centres for the produce certification. An important problem in this industry is the lack of organisations that would group together producers and businesses in food processing, and also poor marketing of regional produce. Measures should be taken to facilitate the development of the processing facilities, and the use of innovative production methods. Designated protected areas and well-established, renowned resorts provide a basis for developing health and health-related tourism in the province. Health tourism involves one-day, or longer, stays outside home, intended to improve physical or mental health of individuals, to receive beauty treatments, or to undergo medical procedures or operations performed by clinics recruiting patients through advertising (Łęcka, 2003, pp. 173-190). Development of health tourism in the region coincides with a general increase in the people's awareness of the necessity of taking care of health and physique, and also with fashion for active leisure time. Therefore, the specialisation emphasises the resort tourism, spa and wellness, and medical tourism. The pro-health tourism is commonly referred to recreational activities and holiday stays. The future of this specialisation is also related to the utilisation of medicinal (sulphide) and thermal waters.

The region's potential in tourism, as regards regional specialisation, is not sufficient. The region does not show specialisation in this area neither with respect to the number of employees nor the GVA generation. The problems are posed by the shortage of accommodation facilities and poor transportation services.

To sum up, construction, and also metallurgy and foundry already significantly affect the economy of the province and are closely related to the internal potential of the region. The province is a leader as regards construction industry contribution to the regional GDP. It is also strongly based on metallurgy, extraction of minerals and agriculture, and has a potential for being competitive in those areas. Modern agriculture and food processing, and also health and health-related tourism produce a lesser impact on the economy of the province at present. Those, however, show a great potential, which, due to smart support, may allow them to develop faster. Thus, regional specialisations selected for the province are based on the 
strengths of the province, but they also cover areas which still gradually build their development potential.

\section{Conclusions}

Regional specialisations, calculated on the basis of the structure of employees and produced GVA, result from historically formed structure of regional economy. The results of calculations differ depending on the method, i.e. the specialisations based on the structure of employees do not coincide with those computed on the basis of the Gross Value Added. Additionally, the dissimilarity indexes established with respect to GVA are lower from those calculated for the number of employees.

The most favourably formed specialisation is found in the Mazowieckie Province, which is characterised by high employment and efficiency in the service industry, especially in financial activities and trade. Significant dissimilarity of the regional economy is shown the Lubelskie Province. The greatest dissimilarity of the structure of the employees from the average one for the country is accompanied by a very high level of specialisation as regards the Gross Value Added. On the one hand, the region is differentiated by the highest share of employment in agriculture, on the other hand, the province displayed one of the highest Krugman indices calculated on the basis of the GVA generated for agriculture and industry sections.

The successive leaders in the dissimilarity of the structure of employees, namely the Podkarpackie and Świętokrzyskie provinces are placed at the end of the ranking based on the GVA. However, high indices of regional specialisations found for the regions of the eastern part of Poland, based on the structure of employees, do not produce unequivocally positive results. The reason is that the most dissimilar structures are found in the provinces, in which low-efficiency agriculture is dominant in the structure of employees.

A relatively low level of specialisation in both categories is found for the Wielkopolskie, Warmińsko-Mazurskie and Opolskie provinces, the specialisation indices of which place those regions only in the second half of the ranking in respect to structure dissimilarity.

The least favourably formed specialisation is found in the KujawskoPomorskie Province. In both rankings, the province is positioned in the last but one place, which means the low dissimilarity of the structure of employees is accompanied by the low dissimilarity of the structure of the GVA generation. 
For the Świętokrzyskie Province, the priorities of the regional innovation policy formulated in RIS3 indicate that four regional specialisations need to be developed, namely: metallurgy and foundry, resource-efficient construction, health and health-related tourism, and also modern agriculture and food processing. The first two specialisations are already well established, those are also closely related to the province's internal potential. However, the specialisations connected with modern agriculture and food processing, or health and health-related tourism produce a modest effect on the present economic position of the province, yet those have a great development potential. Selected regional specialisations include both the areas being already the province's strengths and those that still need to develop their potential. The values of the Krugman index calculated for PKD sections on the basis of the employees and GVA do not allow defining the smart specialisations for the Świętokrzyskie Province. The Krugman indices of dissimilarity calculated for the sections can substantiate the choice of the following specialisations: modern agriculture and food processing, metallurgy and foundry, and resource-efficient construction. It is, however, not possible to assess the choice of health and health-related tourism specialisation on the basis of the data derived from PKD sections.

The identification of regional specialisations for the sake of the regional policies pursued by Poland's provinces is a complex process. Additionally, it must be also considered against the background of the all issues related to territorial development. To establish specialisations as development trajectories of Poland's provinces, it is necessary to make a thorough analysis of economic structures of the regions based both on the inherent resources, e.g. the employees, and also the possibility of generating revenue through, e.g. the commercialisation of regional products. In the context of regional and local development, regional specialisations offer an opportunity to construct competitive advantage. It must be based on distinguishable industry supported by modern technologies, or on a regional product. Other contributing factors include geographical proximity and interrelations between the system participants.

\section{References}

A Strategy for Smart, Sustainable and Inclusive Growth (2010). National Programme of Reforms, Europe 2020, Warsaw: Ministry of Economy.

Bąk, A., Krasowska, M., Piotrowska, M., Sobkiewicz, A., Szymborska A., \& Chmielewski, R., (2008). Doświadczenia i szanse regionów. Przegląd regionalny, 2. 
Chmielewski, R., (2010). Diversification and specialization processes in regional development of new EU countries. Warszawa: Ministerstwo Rozwoju Regionalnego.

Europa 2020. Strategia na rzecz inteligentnego i zrównoważonego rozwoju sprzyjającego wtaczeniu spoteczneти, 2010. Bruksela: Komisja Europejska.

Grosse, T. G., (2002). Przegląd koncepcji teoretycznych rozwoju regionalnego, Studia Regionalne i Lokalne, 1(8).

Jewtuchowicz, A., (2013). Terytorium $i$ wspótczesne dylematy jego rozwoju, Łódź: Wydawnictwo Uniwersytetu Łódzkiego.

Kopczewska, K., (2011). Rola sektora publicznego w przestrzennym rozwoju państwa. Warszawa: CeDeWu.

Krajowa Inteligentna Specjalizacja (KIS), (2014). Warszawa: Ministerstwo Gospodarki.

Krajowa Strategia Rozwoju Regionalnego 2010-2020: Regiony, Miasta, Obszary wiejskie. (2010). Warszawa: Ministerstwo Rozwoju Regionalnego.

Krugman, P., (1991). Geography and Trade, Cambridge: The MIT Press.

Krugman, P., (1979). Increasing Returns to Scale, Monopolistic Competition, and International Trade. Journal of International Economics, 9(4).

Kuciński, K., (1990). Podstawy teorii regionu ekonomicznego, Warszawa: PWN.

Łęcka, I., (2003). Nowe (?) trendy w turystyce zdrowotnej. Prace i Studia Geograficzne, 32 .

Miłek, D., (2013). Specjalizacje regionalne a Strategia Europa 2020, Zarzadzanie i Finanse, 1(2).

National Smart Specialisation (2014), Ministry of Economy, Warsaw, April.

National Strategy for Regional Development 2010-2020: Regions, Cities, Rural areas 2010.

Pieńkowski, M., (2014). Inteligentne specjalizacje a klastry. Retrieved form: http://www.pi.gov.pl/PARP/chapter_86197.asp?soid=427438326EDF45A2935 940951F4B3475 (24.10.2014).

Porter, M., (2001). Porter o konkurencji. Warszawa: PWE.

Research and Innovation Strategy (RIS3). Form Fund Absorption to Outcomes How to Boost the Potential of the Świętokrzyskie Province 2014-2020+, 2014

Smętkowski, M., \& Płoszaj, A., (2011). Duże miasta Polski - wyzwania rozwojowe a interwencja w ramach polityki spójności 2004-2006. Studia Regionalne $i$ lokalne. Wydanie specjalne.

Strategia Badań i Innowacyjności (RIS3). Od absorpcji do rezultatów - jak pobudzić potencjat województwa świętokrzyskiego 2014-2020+, (2014). Kielce: Zarząd Województwa Świętokrzyskiego.

Strategia Innowacyjności i Efektywności Gospodarki „Dynamiczna Polska 2020”, (2013). Warszawa: Ministerstwo Gospodarki.

Szewczuk, A., Kogut-Jaworska, M., \& Zioło, M., (2011). Rozwój lokalny i regionalny. Teoria i praktyka. Warszawa: Wydawnictwo C.H. Beck. 
